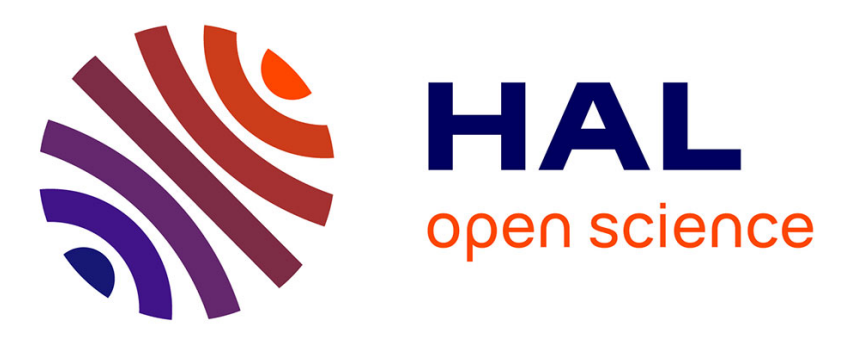

\title{
The effect of functionalizing lipid nanocapsules with NFL-TBS.40-63 peptide on their uptake by glioblastoma cells.
}

Julien Balzeau, Maud Pinier, Raphael Berges, Patrick Saulnier, Jean-Pierre Benoit, Joël Eyer

\section{To cite this version:}

Julien Balzeau, Maud Pinier, Raphael Berges, Patrick Saulnier, Jean-Pierre Benoit, et al.. The effect of functionalizing lipid nanocapsules with NFL-TBS.40-63 peptide on their uptake by glioblastoma cells.. Biomaterials, 2013, 34 (13), pp.3381-9. 10.1016/j.biomaterials.2013.01.068 . hal-03178883

\section{HAL Id: hal-03178883 \\ https://univ-angers.hal.science/hal-03178883}

Submitted on 24 Mar 2021

HAL is a multi-disciplinary open access archive for the deposit and dissemination of scientific research documents, whether they are published or not. The documents may come from teaching and research institutions in France or abroad, or from public or private research centers.
L'archive ouverte pluridisciplinaire HAL, est destinée au dépôt et à la diffusion de documents scientifiques de niveau recherche, publiés ou non, émanant des établissements d'enseignement et de recherche français ou étrangers, des laboratoires publics ou privés. 
Provided for non-commercial research and education use. Not for reproduction, distribution or commercial use.

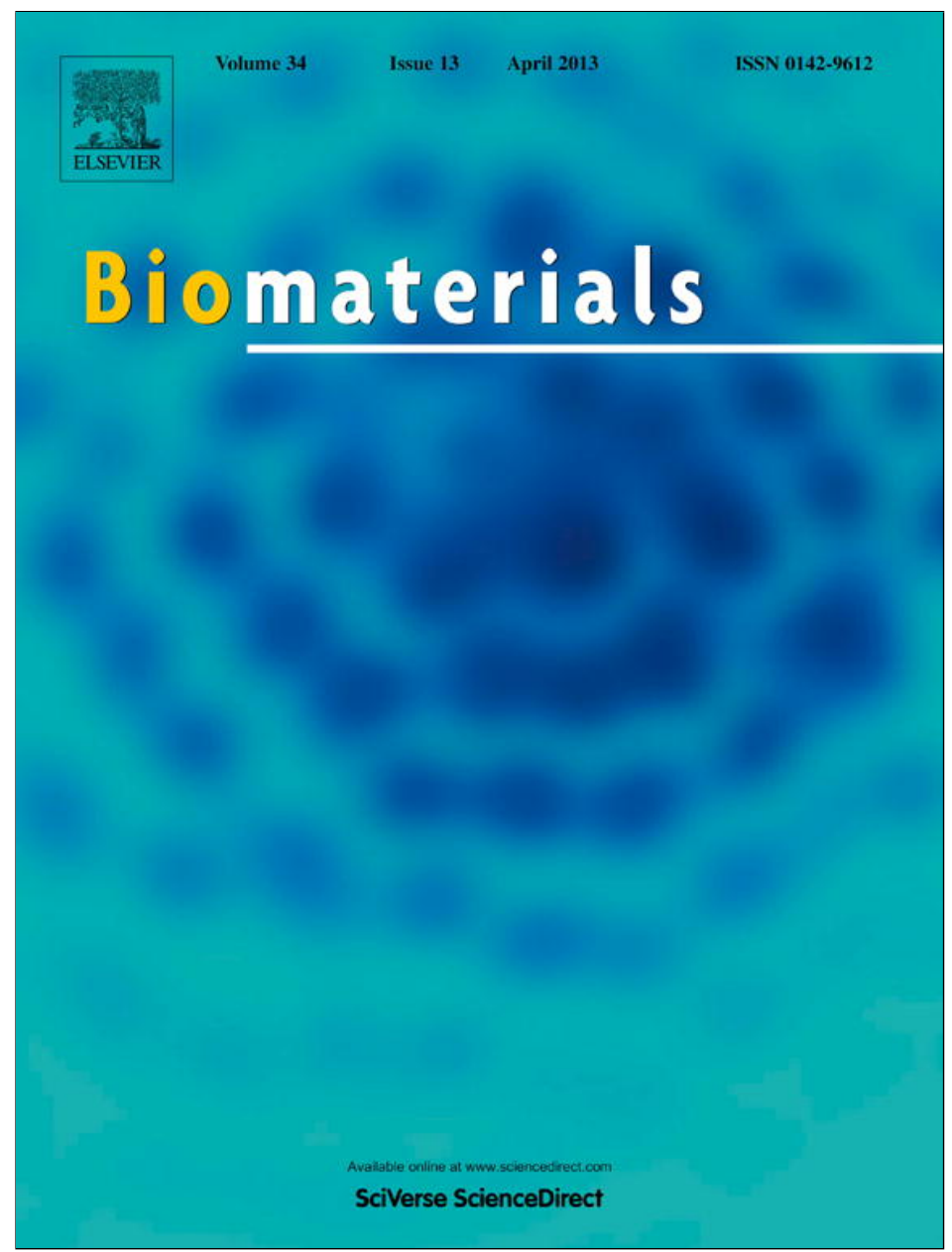

This article appeared in a journal published by Elsevier. The attached copy is furnished to the author for internal non-commercial research and education use, including for instruction at the authors institution and sharing with colleagues.

Other uses, including reproduction and distribution, or selling or licensing copies, or posting to personal, institutional or third party websites are prohibited.

In most cases authors are permitted to post their version of the article (e.g. in Word or Tex form) to their personal website or institutional repository. Authors requiring further information regarding Elsevier's archiving and manuscript policies are encouraged to visit:

http://www.elsevier.com/copyright 


\title{
The effect of functionalizing lipid nanocapsules with NFL-TBS.40-63 peptide on their uptake by glioblastoma cells
}

\author{
Julien Balzeau $^{\mathrm{a}}$, Maud Pinier ${ }^{\mathrm{a}}$, Raphael Berges ${ }^{\mathrm{a}}$, Patrick Saulnier ${ }^{\mathrm{b}}$, Jean-Pierre Benoit ${ }^{\mathrm{b}}$, Joel Eyer ${ }^{\mathrm{a}, *}$ \\ ${ }^{a}$ Laboratoire Neurobiologie E Transgenese, UPRES-EA3143, Bâtiment IBS, Centre Hospitalier Universitaire, LUNAM, 49033 Angers, France \\ ${ }^{\mathrm{b}}$ Micro et Nanomédecine en Thérapeutique (MINT), UMR INSERM 1066, Bâtiment IBS, Centre Hospitalier Universitaire, 49033 Angers, France
}

\section{A R T I C L E I N F O}

\section{Article history:}

Received 18 December 2012

Accepted 15 January 2013

Available online 4 February 2013

\section{Keywords:}

Glioblastoma

Lipid nanocapsules

NFL-TBS.40-63 peptide

Paclitaxel

\begin{abstract}
A B S T R A C T
We previously described a neurofilament derived cell-penetrating peptide, NFL-TBS.40-63, that specifically enters in glioblastoma cells where it disturbs the microtubule network both in vitro and in vivo. The aim of this study is to test whether this peptide can increase the targeted uptake by glioblastoma cells of lipid nanocapsules filled with Paclitaxel, and thus can increase their anti-proliferation in vitro and in vivo. Here, using the drop tensiometry we show that approximately 60 NFL-TBS.40-63 peptides can bind to one $50 \mathrm{~nm}$ lipid nanocapsule. When nanocapsules are filled with a far-red fluorochrome (DiD) and Paclitaxel, the presence of the NFL-TBS.40-63 peptide increases their uptake by glioblastoma cells in culture as evaluated by FACS analysis, and thus reduces their proliferation. Finally, when such nanocapsules were injected in mice bearing a glioma tumour, they are preferentially targeted to the tumour and reduce its progression. These results show that nanocapsules functionalized with the NFL-TBS.40-63 peptide represent a powerful drug-carrier system for glioma targeted treatment.
\end{abstract}

(c) 2013 Elsevier Ltd. All rights reserved.

\section{Introduction}

Malignant glioma represents the most prevalent primary tumour of the central nervous system (about 5 for 100,000), and they can develop at all ages [1]. Despite a combined therapy including surgery when possible, radiotherapy (60 Gy, 30 fractions of $2 \mathrm{~Gy}$ ) and chemotherapy (Temozolomide or Carmustine), the median survival is only $15-18$ months $[2,3]$.

New vectors for the treatment of cancer have been developed to deliver locally anticancer drugs. Some were tested in clinical trials, like liposomes [4,5] and microparticles [6] in many cancers. Use of Carmustine wafer in glioma treatment with radiotherapy and concomitant Temozolomide chemotherapy appears to be safe and feasible, but the beneficial effect is limited [7]. Different innovated vectors are investigated to enhance the delivery of drugs in glioma cells, like liposomes coated with a PEGylated vitamin E [8]. Recently, lipid nanocapsules (LNC) were developed by Heurtault et al. [9], that can be internalized in 9L rat glioma cell line to deliver different molecules, including Paclitaxel [10], Rhenium-188 [11] or Ferrociphenol [12].

Cell-penetrating peptides (CPPs), also known as protein transduction domains, can translocate through cell membranes. Thus,

\footnotetext{
* Corresponding author. Tel.: +3324468 84 88; fax: +3324468 8489 .

E-mail addresses: Joel.eyer@univ-angers.fr, joel.eyer@inserm.fr (J. Eyer).
}

they received a great attention as promising instruments for drug delivery. They were used to deliver drugs, imaging agents, and other possible therapeutic molecules [13]. We recently demonstrated that a peptide derived from the intermediate filament protein neurofilament (NFL-TBS.40-63 peptide) interacts with tubulin and can alter the microtubule network [14]. Moreover, this peptide behaves as a CPP because it enters specifically in rat (9L and F98), mouse (GL261) and human (T98G and U87-MG) glioblastoma cell lines, where it disrupts their microtubule network, without affecting healthy cells like astrocytes or neurons. When injected in Fisher rat bearing an F98 glioma, it provokes a strong reduction of the tumour progression [15].

In this study, our working hypothesis was that this peptide could increase the targeted uptake by glioblastoma cells of lipid nanocapsules filled with Paclitaxel, and therefore could increase their anti-proliferation in vitro and in vivo. To test this hypothesis, we first evaluated by drop tensiometry the binding properties of the NFL-TBS.40-63 peptide to the LNC. Then, the peptide functionalized or unfunctionalized LNC containing DiD (a far-red fluorochrome) and Paclitaxel were tested for their uptake and toxicity on mice glioma and astrocytes. Finally, mice bearing GL261 glioma were treated with different LNC formulations, to determine if the NFL-TBS.40-63 peptide could increase the antitumour property of the Paclitaxel filled nanocapsules, and could restrict their distribution to the tumour and its periphery. 


\begin{tabular}{|c|c|}
\hline \multicolumn{2}{|c|}{ Abbreviations } \\
\hline CED & Convection-Enhanced Delivery \\
\hline BCNU & 1,3-bis(2-chloroethyl)-1-nitrosourea \\
\hline DAPI & $4^{\prime}, 6^{\prime}$-diamidino-2-phenylindole \\
\hline DiD & $\begin{array}{l}1,1^{\prime} \text {-dioctadecyl-3,3,3',3'- } \\
\text { tetramethylindodicarbocyanine, } 4 \text { - } \\
\text { chlorobenzenesulfonate }\end{array}$ \\
\hline DMEM & Dulbecco's Modified Eagle Medium \\
\hline DPBS & Dulbecco's Phosphate Buffered Saline \\
\hline EtOH & ethanol \\
\hline FACS & fluorescence activated cell sorting \\
\hline LNC & lipid nanocapsules \\
\hline LNC-N & $\begin{array}{l}63 \text { peptide } \\
63 \text { anocapsules functionalized with NFL-TBS.40- }\end{array}$ \\
\hline MTS & $\begin{array}{l}\text { 3-carboxymethoxyphenyl-2-(4-sulfophrenyl)-2H- } \\
\text { tetrazolium }\end{array}$ \\
\hline NFL-TBS. & $\begin{array}{l}\text { 40-63 neurofilament light subunit-tubulin-binding- } \\
\text { site.40-63 }\end{array}$ \\
\hline PI & propidium iodide \\
\hline PMS & phenazine methosulfate \\
\hline
\end{tabular}

\section{Materials and methods}

\subsection{Materials}

Biotinylated peptides were synthesized (more than 95\% purity) by Millegen (Toulouse, France). Labrafac ${ }^{\circledR}$ WL 1349 (caprylic-capric acid triglycerides) was purchased from Gattefosse SA (Saint-Priest, France), Solutol ${ }^{\circledR}$ HS15 (Free polyethylene glycol 660 and polyethylene glycol 660 hydroxystearate) from BASF (Ludwigshafen, Germany), Lipoïd ${ }^{\circledR}$ S75-3 (soybean lecithin at $69 \%$ of phosphatidylcholine) from Lipoid Gmbh (Ludwigshafen, Germany), and lipophilic DiD from Invitrogen (Villebon sur Yvette, France). Paclitaxel was purchased from Sigma-Aldrich (Saint Quentin Fallavier, France). Deionized water was produced by a Milli-Q plus system (Millipore, France).

\subsection{Preparation of lipid nanocapsules (LNC)}

\subsubsection{LNC preparation}

50-nm-diameter LNC were prepared according to a previously described process [9]. To obtain LNC suspension, Solutol ${ }^{\circledR}$ HS15 $\left(17 \%\right.$ w/w), Lipoïd ${ }^{\circledR}(1.5 \%$ w/w), NaCl $(1.75 \% \mathrm{w} / \mathrm{w})$, Labrafac ${ }^{\mathbb{B}}(20 \% \mathrm{w} / \mathrm{w})$ and water $(59.75 \% \mathrm{w} / \mathrm{w})$ were mixed and heated $\left(85^{\circ} \mathrm{C}\right)$ under magnetic stirring. Three cycles of progressive heating and cooling between $60{ }^{\circ} \mathrm{C}$ and $85{ }^{\circ} \mathrm{C}$ were carried out. During the last cooling, $27.5 \mu \mathrm{L}$ of DiD (1,1'-dioctadecyl-3,3,3',3'-tetramethylindodicarbocyanine,

chlorobenzenesulfonate, dissolved at $1 \mathrm{mg} / \mathrm{mL}$ in absolute ethanol, Life Technologies, Saint Aubin, France) was added at $78-80^{\circ} \mathrm{C}$. LNC suspension was formed following the irreversible shock induced by the addition of cold deionized water when the temperature was at $70-75^{\circ} \mathrm{C}$. Slow magnetic stirring was then applied to cool down the preparation during $5 \mathrm{~min}$.

\subsubsection{NFL-TBS.40-63-coupled LNC}

After the characterization of LNC (size, polydispersity index, zeta potential), $1 \mathrm{~mL}$ of LNC suspension was incubated during $24 \mathrm{~h}$ with $369 \mu \mathrm{L}$ of $1 \mathrm{~mm}$ NFL-TBS.40-63 peptide dissolved in MilliQ purified water at room temperature in the dark under slow magnetic rotation (NFL-TBS.40-63 final concentration: $0.27 \mathrm{~mm}$ ). For the LNC without peptide (control), $1 \mathrm{~mL}$ of LNC suspension was incubated under the same conditions with $369 \mu \mathrm{L}$ of MilliQ purified water. Then, characterization of the LNCNFL and LNC was carried out to control the quality of LNC.

\subsubsection{Paclitaxel-loaded LNC}

To load anticancer agent into the oily core of the LNC, Paclitaxel was prepared according to Ref. (Garcion) [10]. Briefly, $10 \mathrm{mg}$ of Paclitaxel was dissolved in a solution of $103 \mathrm{mg}$ ethanol, $103 \mathrm{mg}$ of dichloromethane and $5 \mathrm{mg}$ of cholesterol $95 \%$ Solutol HS15, Labrafac, Lipoïd, $\mathrm{NaCl}$ and deionized water were added to this solution, and formulation was done as described above, with evaporation of dichloromethane and ethanol during the process. The final concentration after dilution due to the peptide incorporation was $1.71 \mathrm{~mm}$ of Paclitaxel, according to the initial amount of Paclitaxel.

\subsection{Characterization of the particles}

Nanocapsules were analysed using a Malvern Zetasizer Nano Serie DTS 1060 (Malvern Instruments S.A., Worcestershire, UK). For the measurement, LNC were diluted 1:60 $(v / v)$ in MilliQ purified water. The average hydrodynamic diameter, the polydispersity index and the zeta potential were determined at $25{ }^{\circ} \mathrm{C}$ in triplicate (Table 1).

\subsection{Evaluation of the amount of NFL-TBS.40-63 peptide binding to the LNC}

We evaluated the amount of the NFL-TBS.40-63 peptide adsorbed on purified non-loaded LNC (i.e. without encapsulated drug) using BCA Uptima (Interchim, Montluçon, France). Briefly, the LNC were separated from the water phase using an Amicon ${ }^{\circledR}$ Ultra-0.5 with a $100 \mathrm{kDa}$ cut-off (Millipore, Paris, France). Following the adsorption process, the samples were centrifuged during $30 \mathrm{~min}$ at $4000 \times \mathrm{g}$ to collect the water phase containing the unbound NFL-TBS.40-63 peptide. Then, to recover the LNC with the adsorbed peptide, the filter was placed upside down in a microcentrifuge tube and centrifuged $2 \mathrm{~min}$ at $1000 \times \mathrm{g}$. The original sample and the different fractions were measured. The positive control consisted of free NFLTBS.40-63 peptide.

Each water phase sample (first collection) was diluted $(1: 4 v / v)$. Then, $25 \mu \mathrm{L}$ of each sample was placed into a 96-well plate and $200 \mu \mathrm{L}$ of BCA reagent was added. Absorbance was measured at $562 \mathrm{~nm}$ on a plate reader (SpectraMax M2, Molecular device, USA) following $1 \mathrm{~h}$ incubation at $37^{\circ} \mathrm{C}$. The difference between the free NFLTBS.40-63 peptide and the unbound NFL-TBS.40-63 peptide present in the water phase of the LNC samples represents the fraction of the NFL-TBS.40-63 peptide adsorbed on the LNCS. A calibration curve was performed using increasing concentrations of peptide. The linearity of the titration method for the NFL-TBS.40-63 peptide was verified, up to $800 \mu \mathrm{g} / \mathrm{mL}\left(r^{2}>0.99\right)$. Measurements were performed twice on 3 different batches of LNC-NFL $(n=6)$.

\subsection{Drop tensiometry measurements}

Surface tension measurements were performed at the oil/water interface with a drop tensiometer device (Tracker Teclis, Longessaigne, France). A drop of Labrafac ${ }^{\mathbb{B}}$ (oily phase) was formed using an Exmire microsyringe (Prolabo, Paris, France) into an optical glass cell (Hellma, France) containing the NFL-TBS.40-63 peptide (up to $12.85 \cdot 10^{-5} \mathrm{M}$ ) solubilized in MilliQ water (aqueous phase). The axisymmetric shape of the rising drop was analysed in real time at room temperature using a video camera connected to a computer. The volume of the droplet was maintained constant $(5 \mu \mathrm{L})$ using a stepping motor connected to a microcomputer to control the drop volume in order to get a link between molecule adsorption and the surface tension. Saturation is obtained once the tension reached a plateau. Measurements were performed on 3-8 independent droplets. Each surface tension was calculated once equilibrium was reached, and corresponds to the complete saturation of the interface.

In another set of experiments Solutol ${ }^{\circledR}\left(10^{-4} \mathrm{M}\right)$ was adsorbed at the oil/water interface, and once the equilibrium was reached, the NFL-TBS.40-63 peptide was added in the aqueous phase and compared to Solutol ${ }^{\circledR}$-NFL-TBS.40-63 concomitan adsorption. Surface tension values were recorded, once the surface tension reached a plateau. Measurements were performed on 3 independent droplets. For the calculation of the surface pressure, densities of products, 0.945 and 0.999 , for Labrafac ${ }^{\circledR}$ and water respectively, at $25{ }^{\circ} \mathrm{C}$, were taken into account.

\subsection{Cellular analysis of LNC uptake by flow cytometry and fluorescent microscopy}

For flow cytometer analysis, GL261 glioma cells and primary astrocytes [16] were seeded in 6 -well plates at $4 \times 10^{5}$ cells per well for $12 \mathrm{~h}$ at $37{ }^{\circ} \mathrm{C} / 5 \% \mathrm{CO}_{2}$.

Table 1

Physicochemical characteristics of different LNC formulations.

\begin{tabular}{lllr}
\hline & Mean particle size $(\mathrm{nm})$ & Polydispersity PDI & Zeta potential (mV) \\
\hline LNC & $56.22 \pm 0.05$ & $0.046 \pm 0.009$ & $-8.70 \pm 1.21$ \\
LNC-NFL & $58.17 \pm 0.10$ & $0.085 \pm 0.010$ & $-6.01 \pm 0.47$ \\
LNC-(Paclitaxel) & $54.73 \pm 0.10$ & $0.123 \pm 0.004$ & $-8.45 \pm 1.93$ \\
LNC-(Paclitaxel)-NFL & $57.90 \pm 0.16$ & $0.175 \pm 0.011$ & $-5.27 \pm 0.50$ \\
\hline
\end{tabular}


LNC-(DiD), LNC-(DiD)-NFL and vehicle were incubated at different dilutions (1:100, $1: 200,1: 400$ and 1:1000) for $6 \mathrm{~h}$ in fresh DMEM (Dulbecco's Modified Eagle Medium, Lonza, Levallois-Perret, France). After incubation, cells were washed twice with DPBS (Dulbecco's Phosphate Buffered Saline, Lonza, Levallois-Perret, France) and incubated with Trypsin-EDTA $1 \times$ (Sigma, St Quentin Fallavier, France) for 15 min, to release LNC attached to the membrane. Cells were washed 3 times with PBS, centrifuged at $2000 \mathrm{rpm}$ for $5 \mathrm{~min}$, and counterstained with propidium iodide (PI, Sigma-Aldrich, St Quentin Fallavier, France) before analysis on a BD FACSCalibur fluorescent-activated flow cytometer and using the BD CellQuest Software (BD Biosciences). Experiments were done in triplicate, and 20,000 cells were measured for each experiment.

For the fluorescent microscopy analysis, cells were cultured in 2-wells Lab-Tek chambers ( 1000 cells per well, Thermo Fisher Scientific, USA) for $12 \mathrm{~h}$ before incubation with the different formulations or vehicle for $6 \mathrm{~h}$. After incubation, medium was discarded, and $1 \mathrm{~mL}$ of fresh DPBS was added per well. Cells were analysed with an inverted fluorescent microscope (Leica DMI6000 with a CoolSNAP-HQ2 camera), and using the Metamorph 7.1.7.0 software to evaluate the DiD fluorescence.

\subsection{Cell viability analysis}

Mouse glioma cells (GL261, $2 \times 10^{4}$ cells $/ \mathrm{mL}$ ) and primary astrocytes $\left(1 \times 10^{6}\right.$ cells $\left./ \mathrm{mL}\right)$ were prepared [16], and $200 \mu \mathrm{L}$ of such a cell suspension was incubated in 96-well plates for $24 \mathrm{~h}$. Then, the culture media was removed and different LNC formulations diluted in fresh media were tested for $72 \mathrm{~h}$ at $37^{\circ} \mathrm{C}$. Following the treatment, $100 \mu \mathrm{L}$ of fresh media was added in each well, and cell viability was measured using the MTS/PMS survival assay. Briefly, $25 \mu \mathrm{L}$ of a mixture of MTS (3-carboxymethoxyphenyl-2-(4-sulfophrenyl)-2H-tetrazolium, Promega, Madison, USA) and PMS (phenazine methosulfate, Promega, Madison, USA) at an MTS-to-PMS ratio of 1:20 was added to the fresh media for $4 \mathrm{~h}$ of incubation. The number of living cells is directly proportional to the intensity of colouration measured by the amount of $490 \mathrm{~nm}$ light absorbance in a SpectraMax M2 multi-scanning spectrophotometer. The absorbance determined following the incubation of cells with only the culture media was considered as $100 \%$ survival.

\subsection{In vivo experiments of C57Bl6 mice bearing GL261 glioma}

Female C57Bl6 mice (7-8 weeks old) were obtained from Charles River Laboratories (L'Arbresle, France). All experimental procedures and animal care were carried out in conformity with the guidelines of the European regulations. Mouse GL261 cells were detached with Trypsin-EDTA $1 \times$, washed twice in DMEM, counted, and diluted at $25 \times 10^{6}$ cells per mL. Animals ( 5 per group) were anesthetized by intraperitoneal injection of a mixture of Ketamine $10 \%(0.8 \mu \mathrm{L} / \mathrm{g})$ and Xylazine $2 \%$ $(0.5 \mu \mathrm{L} / \mathrm{g}) .2 \mu \mathrm{L}$ of the cell suspension were injected by stereotaxy in the right striatum, $1 \mathrm{~mm}$ anterior and $2 \mathrm{~mm}$ lateral to the bregma, $3.5 \mathrm{~mm}$ deep, at a flow rate of $0.5 \mu \mathrm{L}$ per minute.

Six days after the GL261 cells implantation, $10 \mu \mathrm{L}$ of LNC-(DiD), LNC-(DiD)-NFL, LNC-(DiD, Paclitaxel), LNC-(DiD, Paclitaxel)-NFL or vehicle were injected by slowinfusion CED (Convection-Enhanced Delivery) with an osmotic pump, at the same coordinates and the same flow rate. This volume corresponds to $14.6 \mu \mathrm{g}$ of Paclitaxel per animal, according to the initial amount of Paclitaxel.

Animals were monitored each day for their clinical status (weight, ataxia, periorbital haemorrhage), and sacrificed 21 days after cells injection. Before euthanasia, mice were analysed with the multispectral Maestro Imaging System (CRI, Caliper Life Sciences, USA) and using the Maestro 2.10.0 software to determinate if brains were still fluorescent for DiD. Brains were then removed, frozen in isopentane at $-30{ }^{\circ} \mathrm{C}$ and stored at $-80^{\circ} \mathrm{C}$ before analysis.

\subsection{Histological analysis and measurement of tumour size}

Serial sections ( $20 \mu \mathrm{m}$ thick) of frozen brains were obtained using a Leica cryostat, and stained with haematoxylin and eosin to distinguish tumour from the healthy tissue. Images of sections were captured with a Leica Z16APO macroscope using the Leica Application Suite 2.8.1 software. The tumour area was measured with the ImageJ software, and knowing the thickness of all sections, the volume of the tumour was calculated.

\subsection{Immunohistochemical analysis of LNC localization in brain section}

Frozen brain sections ( $12 \mu \mathrm{m}$ ) were dried for $30 \mathrm{~min}$ at room temperature in the dark to protect DiD fluorescence before montage with Vectashield ${ }^{\circledR}$ Hard Set Mounting Medium containing DAPI ( $4^{\prime}, 6^{\prime}$-diamidino-2-phenylindole, Vector Laboratories, Burlingame, USA). The pictures were taken using a Leica DMI6000 inverted microscope and a CoolSNAP-HQ2 camera, and analysed with the Metamorph 7.1.7.0 software.

\subsection{Statistical analysis}

Data are presented as mean \pm S.E.M. (bars). Cellular incorporation, viability data and tumour size were analysed with Student's $t$-test using Prism 4.00 (GraphPad software, San Diego, USA). Asterisks indicate significant level ${ }^{*} p<0.05 ;{ }^{* *} p<0.005$ and ${ }^{* * *} p<0.001$.

\section{Results}

\subsection{Fixation and quantification of the amount of NFL-TBS.40-63 peptide on $L N C$}

The lipid nanoparticles (LNC) were widely described as cargo for various components $[10,11]$. Recently, we showed that the NFLTBS.40-63 peptide selectively targets glioblastoma cells both in vitro and in vivo [15]. Here, we determined if such LNC could be functionalized with this peptide to improve their targeted uptake by glioblastoma.

LNC were prepared using an emulsion inversion phase process [9]. Particles were characterized using a Malvern Zetasizer (Table 1). The average size of particles is $56.22 \pm 0.05 \mathrm{~nm}$ and $54.73 \pm 0.1 \mathrm{~nm}$ for respectively LNC and LNC-Paclitaxel. The polydispersity index for the different formulations is always inferior at 0.2 , indicating a unique population of spherical nanoparticles with a diameter about $55 \mathrm{~nm}$. The zeta potential is slightly negative $(-8.7 \pm 1.21 \mathrm{mV}$ and $-8.45 \pm 1.93 \mathrm{mV}$ for LNC and LNC-Paclitaxel respectively), due to the presence of PEG at the surface, reducing the non-specific binding of LNC.

After particles characterization, $1 \mathrm{mg}$ of solubilized NFL-TBS.4063 peptide ( $1 \mathrm{~mm}$ ) was added to $1 \mathrm{~mL}$ of formulation and incubated at room temperature to allow peptide adsorption. After $24 \mathrm{~h}$ of incubation, LNC with or without peptide were again characterized. The size of LNC-NFL and LNC-Paclitaxel-NFL is $58.17 \pm 0.1 \mathrm{~nm}$ and $57.9 \pm 0.16 \mathrm{~nm}$ respectively, with a slightly increase compared to LNC without peptide. The polydispersity is still under 0.2 , demonstrating that no aggregates are formed in the preparation. The zeta potential is slightly negative $(-6.01 \pm 0.47 \mathrm{mV}$ and $-5.29 \pm 0.5 \mathrm{mV}$ ), with a little increase compared to LNC without peptide.

To gain further insight on the interactions between the LNC and the NFL-TBS.40-63 peptide a study of the tension active properties was firstly performed. The surface tension at an interface Labrafac ${ }^{\circledR} /$ Water with increasing amount of NFL-TBS.40-63 peptide was measured on a rising drop with a drop apparatus. The surface tension measured in the presence of increasing concentrations of the NFL-TBS.40-63 peptide progressively decreased (Fig. 1A), which indicates that the peptide exhibits surfactant property.

To determine whether the NFL-TBS.40-63 molecules are inserted between Solutol ${ }^{\circledR}$ molecules at the LNC interface or adsorbed, surface tension was measured at an interface Labrafac ${ }^{\circledR} /$ Water containing Solutol $^{\circledR}\left(10^{-4} \mathrm{M}\right)$ and the NFL-TBS.40-63 peptide. This surface tension was compared to a stabilized interface Labrafac ${ }^{\circledR}$ / Water containing Solutol ${ }^{\circledR}\left(10^{-4} \mathrm{M}\right)$ followed by the addition of the NFL-TBS.40-63 peptide. As shown in Fig. 1B, the tension remains stable and no statistical difference was observed between the two types of measures. Thus, the interfacial behaviour suggests an interaction with the polar PEG groups of the Solutol ${ }^{\circledR}$ and not directly with Labrafac ${ }^{\circledR}$. All these results demonstrate that the NFLTBS.40-63 peptide is adsorbed at the surface of the surfactant layer, illustrated in Fig. 1C.

To evaluate the amount of NFL-TBS.40-63 peptide adsorbed on the LNC, BCA assay was performed after LNC-NFL centrifugation using an Amicon ${ }^{\circledR}$ Ultra-0.5 with a $100 \mathrm{kDa}$ cut-off. LNC-NFL stay in the upper side of the Amicon ${ }^{\circledR}$, and unbounded peptide is eluted in the water phase. A peptide calibration curve with BCA assay was compared to this water phase value, and thus unbounded peptide was calculated as $51.7 \pm 7 \%$ of the initial amount. Consequently, the NFL-TBS.40-63 adsorption on the peptide was estimated to be $48.3 \pm 7 \%$. Assuming that LNC have a spherical shape, that the 

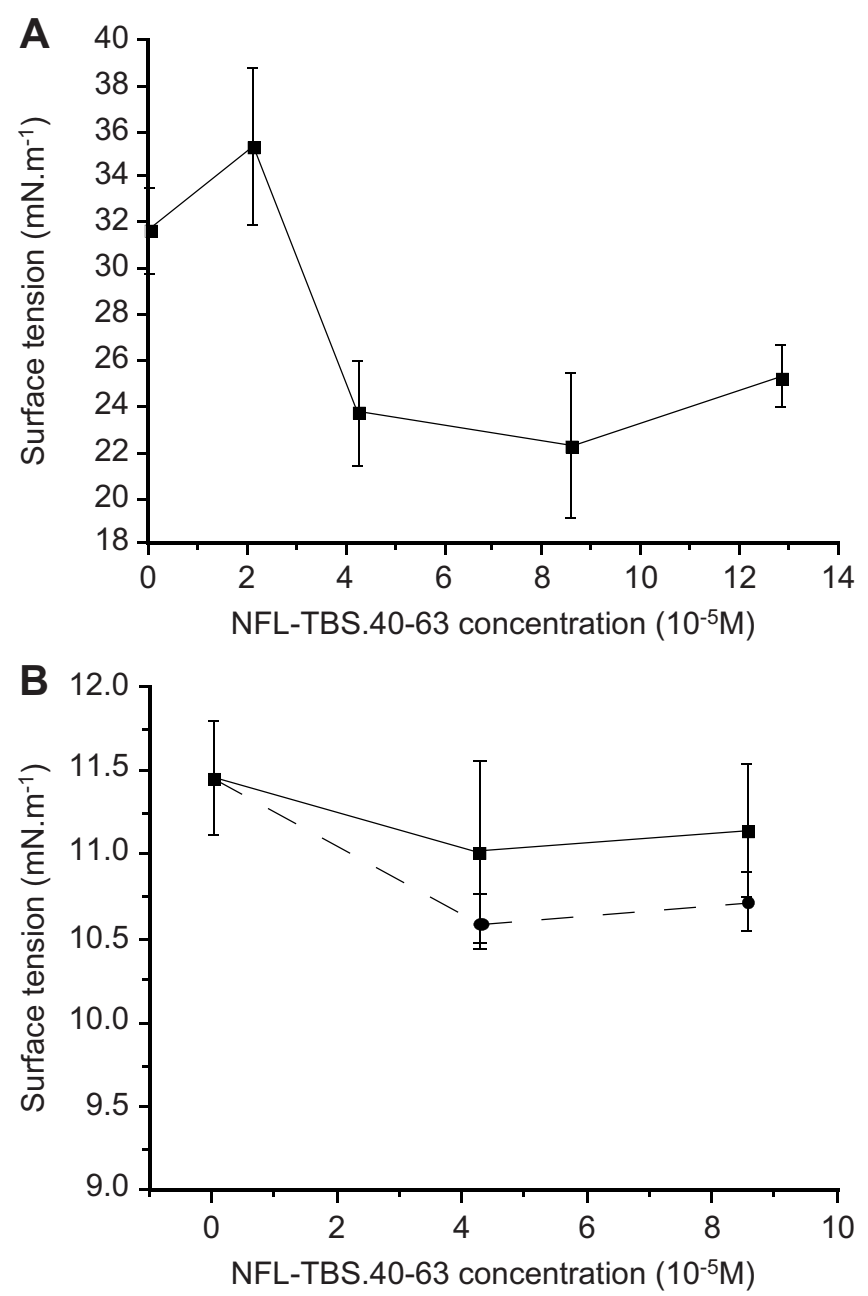

C
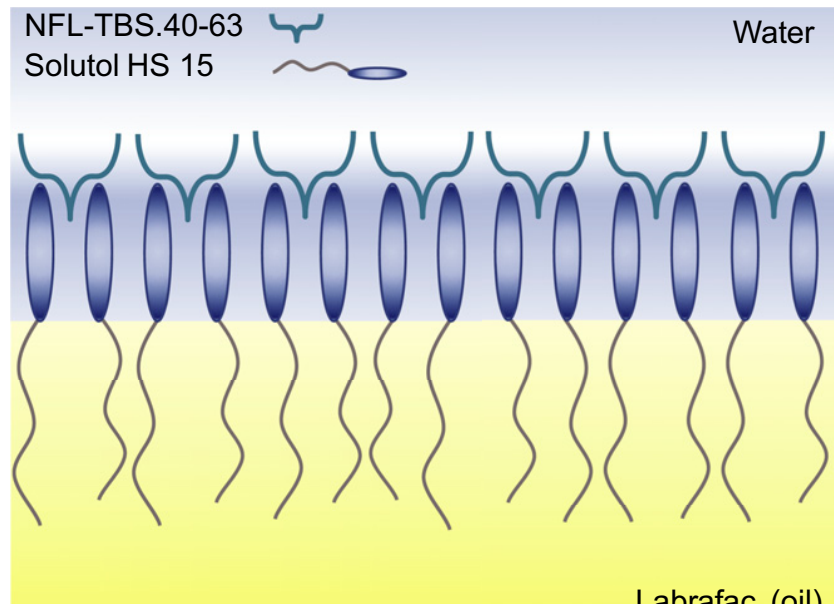

Labrafac (oil)

Fig. 1. Characterization of the interaction between the NFL-TBS.40-63 peptide and LNC. A: Increasing amount of the NFL-TBS.40-63 peptide decreases the surface tension measured at a Labrafac ${ }^{\circledR} /$ water interface of a rising drop. Means \pm SD; displayed from 3 to 8 different droplets. B: Increasing the amount of the NFL-TBS.40-63 peptide has no influence on the surface tension measured at a Labrafac ${ }^{\circledR} /$ water containing Solutol ${ }^{\circledR}$ interface of a rising drop, during the formation of the interface (solid line), nor after the stabilization of the interface (dashed line). Means \pm SD; displayed from 3 different droplets. C: A schematic representation of the interfacial organization of NFL-TBS.4063 adsorbed at the LNC surface. whole input quantities of Labrafac ${ }^{\circledR}$ and Lipoid ${ }^{\circledR}$ are confined into the capsules and that the radius of a $56.22 \mathrm{~nm} \mathrm{LNC}$ is about $23.61 \mathrm{~nm}$ (plus $4.5 \mathrm{~nm}$ of PEG) [17], we determined that the volume of one nanoparticle is $5.44 \times 10^{4} \mathrm{~nm}^{3}$ and that there is $2.15 \times 10^{15}$ nanoparticles in $1 \mathrm{~mL}$ of the preparation. We added $1 \mathrm{mg}$ of peptide (2712 $\mathrm{g} \mathrm{mol}^{-1}$ ) corresponding to $2.22 \times 10^{17}$ molecules of peptide. With an adsorption estimated to $48.3 \pm 7 \%$, its leads to approximately from 43 to 58 molecules of NFL-TBS.40-63 per nanoparticle.

\subsection{The NFL-TBS.40-63 peptide enhances LNC incorporation}

We demonstrated previously that the NFL-TBS.40-63 peptide can enter in mouse glioma cell lines (GL261), but it poorly penetrates in normal cells (astrocytes and neurons) [14,15]. Here, we evaluated the capacity of LNC containing DiD fluorochrome and functionalized or not with the NFL-TBS.40-63 peptide to target and penetrate glioma cells. The incorporation of fluorescent LNC in glioma cells was evaluated by FACS and fluorescence microscopy.

Following $6 \mathrm{~h}$ of incubation, the fluorescently filled LNC show a preferential internalization in cells when functionalized with NFL-TBS.40-63 peptide (Fig. 2A). When tested on GL261 cells and astrocytes, respectively $57.7 \pm 4.7 \%$ and $51.1 \pm 6.8 \%$ of the cells incorporate LNC-(DiD)-NFL for a $1 / 100$ dilution, versus $9.4 \pm 3.7 \%$ and $10 \pm 1.9 \%$ for LNC-(DiD) cells. Depending on the dilutions used, the functionalization of LNC with the NFL-TBS.40-63 peptide increases the entrance 6-13 fold in GL261 cells and 5-7 fold in astrocytes. The improvement of the uptake is also evidenced using fluorescence microscopy (Fig. 2B and C), where the detection of DiD is clearly increased in LNC-(DiD)-NFL treated cells when compared to $\mathrm{LNC}-(\mathrm{DiD})$ treated cells.

\subsection{Cell viability}

We evaluated the effect of LNC formulations on cell survival of GL261 cells and mouse astrocytes. Following $72 \mathrm{~h}$ of incubation, $34.3 \pm 0.8 \%$ of glioma cells treated with the highest dose of Paclitaxel survives, compared to $44.7 \pm 2.6 \%$ and $53 \pm 2 \%$ for LNCPaclitaxel-NFL and LNC-Paclitaxel respectively (Fig. 3A and B). The LNC without Paclitaxel are not toxic for these cells, whether they are functionalized or not with the NFL-TBS.40-63 peptide. Similarly, the NFL-TBS.40-63 peptide at this dilution is not toxic (data not shown). The same assay was repeated on mice astrocytes primary cultures (Fig. 3C and D). These cells are less sensitive to Paclitaxel used at the same concentration ( $81 \pm 1.6 \%$ of survival cells), and no major effect on viability was detected after LNC-Paclitaxel or LNCPaclitaxel-NFL treatment $(100.8 \pm 4.4 \%$ and $94.8 \pm 4.3 \%$ respectively). The LNC containing DiD were also tested, but no difference was observed compared to non-fluorescent LNC (data not shown).

\subsection{Localization of LNC in the brain of mice bearing GL261 glioma}

For the in vivo studies, different sets of LNC containing DiD were injected by stereotaxy in the striatum 6 days after the tumour implantation. After 15 days, the DiD induced fluorescence can be detected with the multispectral Maestro Imaging System (Fig. 4A). At this macroscopic level, almost all the DiD fluorescence can be detected in the right striatum.

A detailed analysis on $12 \mu \mathrm{m}$ thick serial sections (Fig. 4B) and using a fluorescent microscope reveals that the fluorescence on the sections of brains treated with the LNC-(DiD)-NFL is clearly increased when compared to those treated with the LNC-(DiD) that were not functionalized with the peptide. A similar result is observed when LNC also contain Paclitaxel. This shows that the NFL-TBS.40-63 peptide increases the uptake of LNC by the tumour. Moreover, while almost all the fluorescence is localized to the 

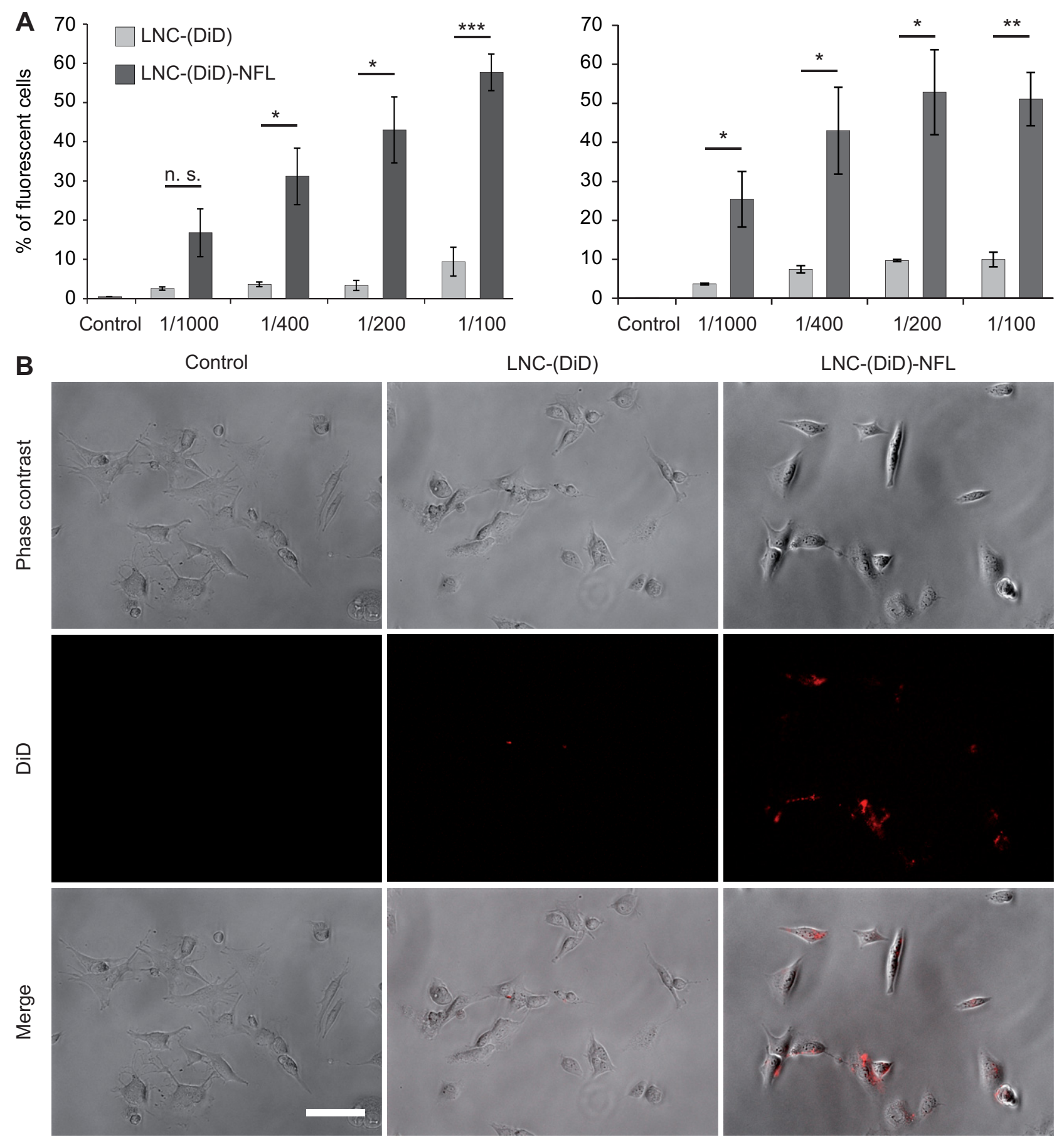

C
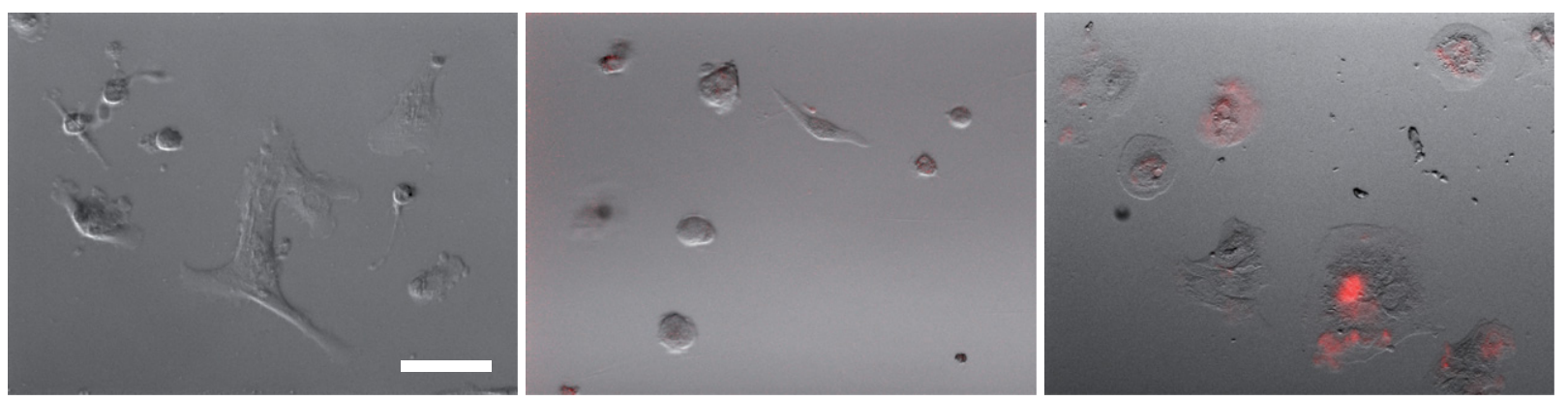

Fig. 2. Preferential incorporation in GL261 cells and mouse astrocytes of LNC grafted with the NFL peptide. A: GL261 cells (left panel) or mouse astrocytes (right panel) were incubated with different dilutions (1/100; 1/200; 1/400 and 1/1000) of LNC-(DiD) and LNC-(DiD)-NFL for 6 h. The fluorescence of DiD was measured using a FACSCalibur flow cytometer (Becton Dickinson). Statistically significant differences were evaluated by Student's $t$-test $\left({ }^{*} p<0.05 ;{ }^{* *} p<0.005 ;{ }^{* * *} p<0.001\right)$. B: GL261 cells incubated during $6 \mathrm{~h}$ in the presence of LNC-(DiD), LNC-(DiD)-NFL or PBS (1/100) in Lab-Tek chambers, and then observed with an inverted fluorescent microscope. Scale bar $=50 \mu \mathrm{m}$. C: Mouse astrocytes incubated during $6 \mathrm{~h}$ in the presence of LNC-(DiD), LNC-(DiD)-NFL or PBS (1/100) in Lab-Tek chambers, and then observed with an inverted fluorescent microscope. Scale bar $=50 \mu \mathrm{m}$. 

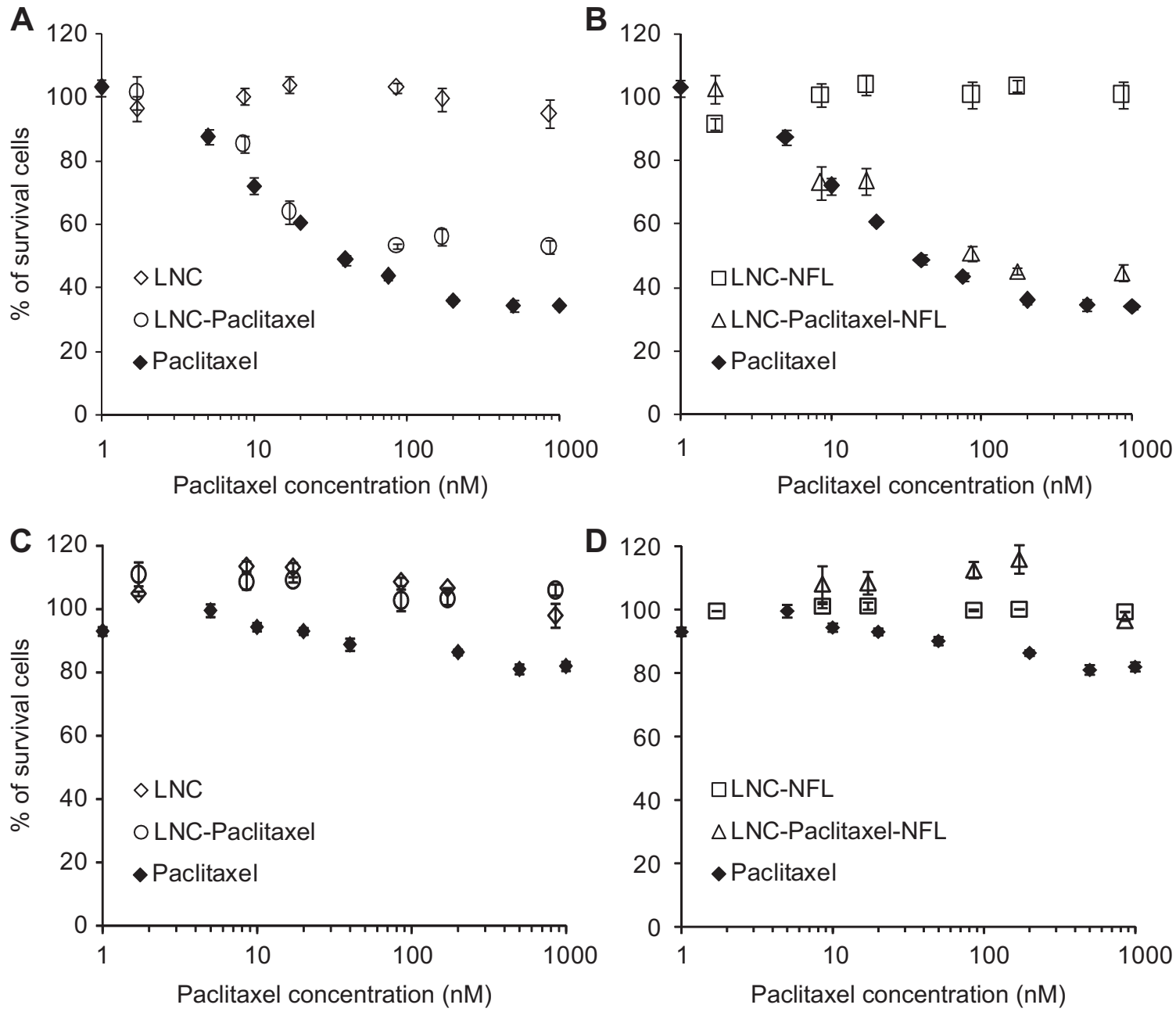

Fig. 3. Cytotoxicity effects of different LNC on GL261 cells and mouse astrocytes. The cell survival of GL261 cells (A and B) and mouse astrocytes (C and D) was determined by MTS Cytotoxicity assay (Promega) after $72 \mathrm{~h}$ of treatment with various concentrations of Paclitaxel alone, and LNC with or without Paclitaxel and functionalized or not with NFL-TBS.4063 peptide.

tumour when the animals are treated with the LNC functionalized with the NFL-TBS.40-63 peptide, several fluorescent signals can be found in the left hemisphere (which does not contain the tumour) when the LNC are not functionalized with the peptide. These observations clearly indicate that the LNC are well targeted to the tumour when they are functionalized with the NFL-TBS.40-63 peptide, while many LNC are not localized to the tumour when they are not functionalized with the peptide.

3.5. Effects of Paclitaxel filled LNC, alone or functionalized with the NFL-TBS.40-63 peptide on C57Bl/6 mice bearing GL261 glioma

Mice bearing GL261 glioma were monitored every day for their behaviour and weight variations (Fig. 4C). After 21 days, mice in the control group showed a loss of weight of $8.7 \pm 1.3 \%$ compared to their initial weight and only $3.9 \pm 5.5 \%$ for the LNC-Paclitaxel group (total Paclitaxel dose: $0.8 \mathrm{mg} / \mathrm{kg}$ body weight). On the opposite, the LNC-Paclitaxel-NFL treated mice present an increase of $1.6 \pm 1.5 \%$ of their weight. Morphometry studies indicate that the LNC without Paclitaxel show no effect on the tumour size, whether they are functionalized or not with the NFL-TBS.40-63 peptide (Fig. 4B and D). On the opposite, when the mice are treated with the LNC containing Paclitaxel, the tumour volume was reduced from $96 \pm 15.1 \mathrm{~mm}^{3}$ to $38.8 \pm 10.9 \mathrm{~mm}^{3}$, corresponding to a $60 \%$ reduction of the tumour volume. When the mice are treated with the LNC-Paclitaxel previously functionalized with the NFL-TBS.4063 peptide, the tumour volume was reduced to $24.1 \pm 8.2 \mathrm{~mm}^{3}$, corresponding to a $75 \%$ reduction of the tumour volume. This clearly shows that the NFL-TBS.40-63 peptide significantly increased the anti-proliferative activity of the Paclitaxel filled LNC.

\section{Discussion}

We previously showed that intermediate filaments are able to fix tubulin dimers on specific sites named tubulin-binding sites (TBS) [14]. Peptides corresponding to these sequences show different properties, including the capacity to alter tubulin polymerization or to penetrate in nuclei of glioma cells [18]. A peptide corresponding to the TBS sequence located on the neurofilament light subunit (NFL-TBS.40-63), can interact in vitro with tubulin, and can enter in multiple glioma cell lines where it inhibits the proliferation of glioma cells by altering their microtubule network. On the opposite, the peptide has no, or poor activities on the other cells of the nervous system, like astrocytes or neurons. Finally, when the peptide is injected in Fischer rats bearing an F98 glioma, it penetrates in the tumour and provokes a strong reduction of its development [15].

In this study, we further investigated the capacity of the NFLTBS.40-63 peptide to target mouse glioma cells when it is coupled to lipid nanocapsules. Different methods to attach the peptide were tested using biotin- or amino-modified DSPE-PEG, but the 
A

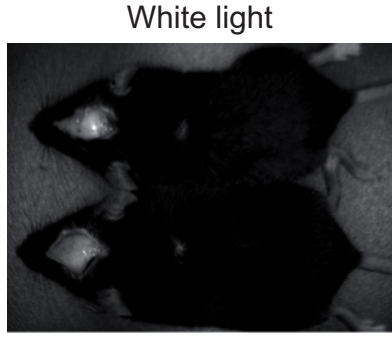

DiD

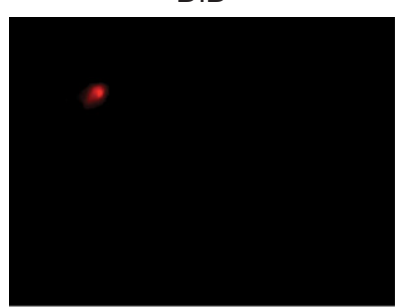

Merge

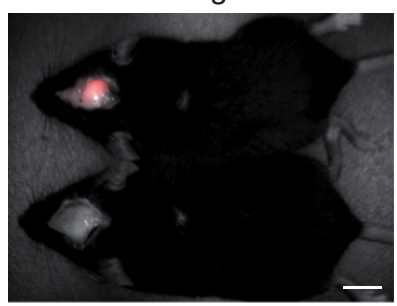

B

Hematoxylin/Eosin
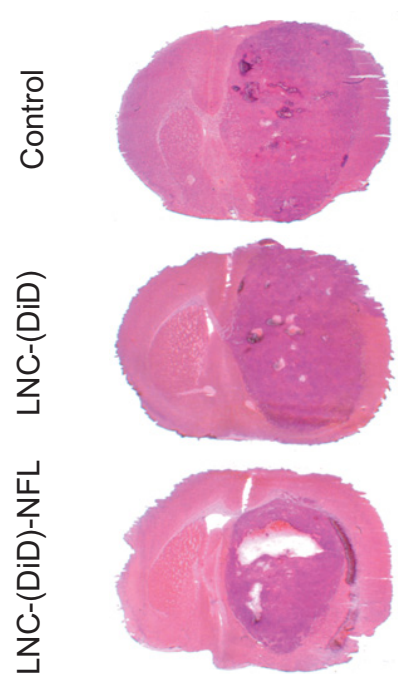

号

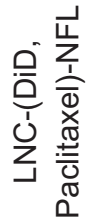

C

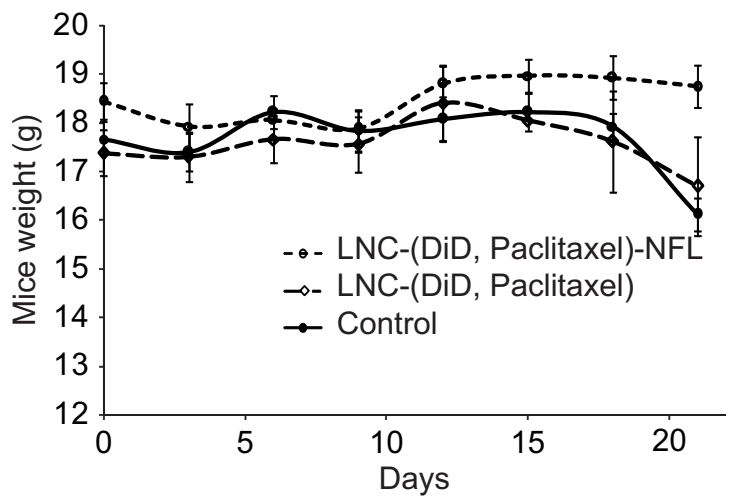

DAPI 10x
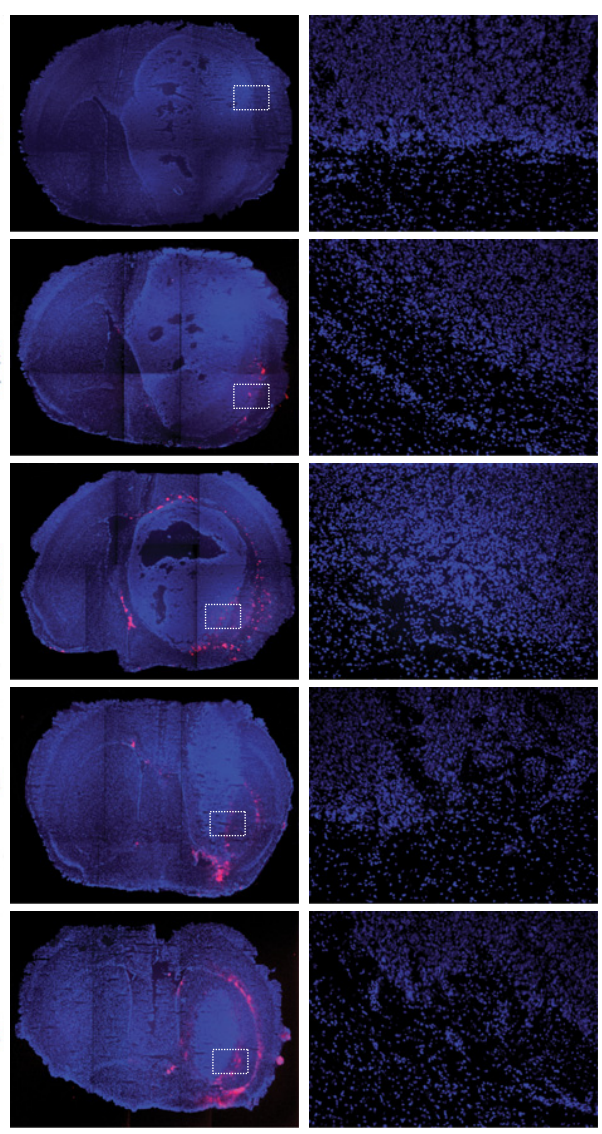

$\operatorname{DiD} 10 x$
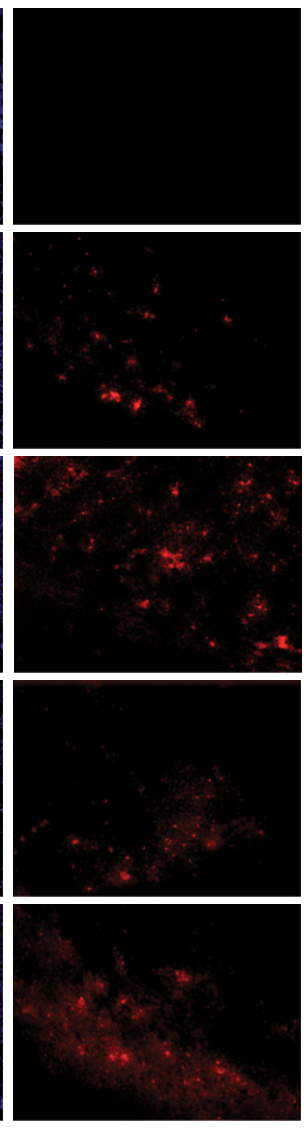

Merge 10x
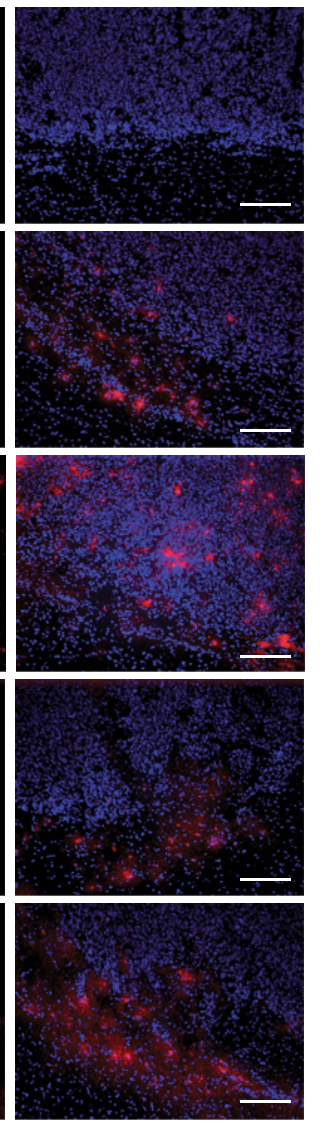

D

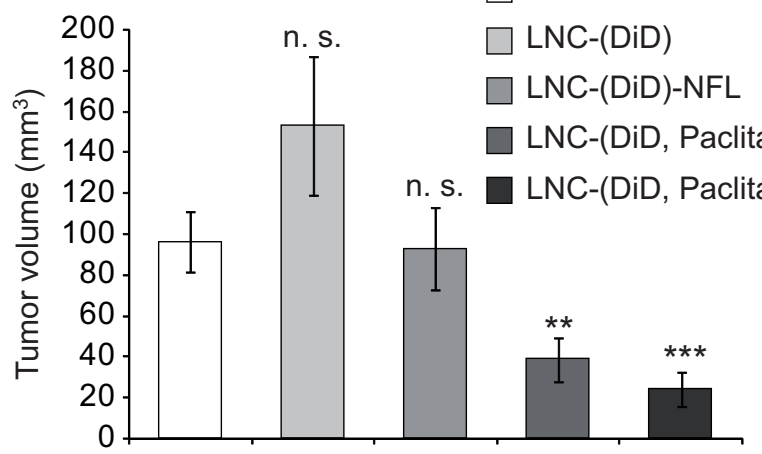

Fig. 4. In vivo localization and effects of the different LNC on tumour size following their injection in mice brain bearing a GL261 tumour. A: Pictures of mice bearing a tumour 21 days after the implantation of GL261 cells and 15 days after the intra-tumoral injection of LNC. The upper mouse was treated with $10 \mu \mathrm{L}$ of LNC-(DiD)-NFL and the lower mouse with $10 \mu \mathrm{L}$ of vehicle. DiD was localized with the multispectral Maestro imaging system (CRI, Caliper Life Sciences). Scale bar $=1 \mathrm{~cm}$. B: Coronal sections of the brain stained with hematoxylin/eosin (line on the left) or immunofluorescently stained with Vectashield ${ }^{\circledR}$ containing DAPI (lines on the right). Red fluorescence shows LNC containing DiD. Scale bar $=200 \mu \mathrm{m}$. C: Daily weight monitoring of the animals during the experiment. Weights are represented as the mean of five animals in each group, \pm standard deviation. D: Tumour volumes of C57Bl6 mice bearing a GL261 glioma and treated with $10 \mu \mathrm{L}$ of different formulations (LNC-(DiD), LNC-(DiD)-NFL, LNC-(DiD, Paclitaxel), LNC-(DiD, Paclitaxel)NFL or control). Statistically significant differences were evaluated by Student's $t$-test compared to control $\left({ }^{* *} p<0.005 ;{ }^{* * *} p<0.001\right.$; n. s.: not significant). (For interpretation of the references to colour in this figure legend, the reader is referred to the web version of this article.) 
internalization of LNC by cells was not increased following such coupling (data not shown). This probably reflected an alteration of the structure and function of the peptide [19]. On the opposite, incubation during $24 \mathrm{~h}$ of the LNC with the NFL-TBS.40-63 peptide without any additional product allows an increased uptake in cells. Dialysis of nanocapsules after the grafting of the peptide to eliminate unbounded and excessive peptide did not modify the uptake compared to undialysed LNC-NFL (data not shown). To test whether the grafting of the peptide to $\mathrm{LNC}$ is essential, we also co-incubated LNC with free NFL-TBS.40-63 peptide at $20 \mu \mathrm{m}$ (data not shown) with cells, but the uptake was similar as LNC without peptide, indicating that the $24 \mathrm{~h}$ incubation for the attachment of the peptide to LNC is necessary. Additional experiments with different LNC and/or peptide concentrations will be proceeding, to confirm these results. The net positive charge at physiological $\mathrm{pH}(\mathrm{pI}=10.3)$ of the NFL-TBS.40-63 peptide, the negative zeta potential (c.a. $-8.5 \mathrm{mV}$ ) at the surface of LNC and the decrease of zeta potential after $24 \mathrm{~h}$ of incubation with the peptide (c.a. $-6 \mathrm{mV}$ ) indicate the formation of electrostatic interactions and a direct adsorption of the peptide (Fig. 1C). The adsorption on the LNC means that the structure of the peptide is still available for the preferential cell recognition as described previously [19].

Interestingly, the in vitro uptake of LNC by mice astrocytes is also enhanced at the same rate as the uptake by glioma cells by the adsorption of the NFL-TBS.40-63 peptide, abolishing the preferential uptake of NFL-TBS.40-63 peptide for glioma cells (Fig. 2). The diminution of the negative charge of LNC after the adsorption of the peptide could facilitate a general uptake by cells. Alternatively, the structural motif of the peptide responsible for its preferential uptake by glioblastoma cells versus astrocytes [19] could be partially hidden or affected by its bidding to LNC. Further identification of the internalization pathway of the NFL-TBS.40-63 peptide and characterization of the binding strengths by surface plasmon resonance may provide additional information on this process.

The NFL-TBS.40-63 peptide has been shown to reduce in vitro the proliferation of glioblastoma cells, and in vivo the tumour growth when injected to rat bearing F98 glioma [15]. Thus, the presence of the peptide together with the LNC could have a similar activity. However, when Paclitaxel (20 nm) and the NFL-TBS.40-63 peptide (up to $100 \mu \mathrm{m}$ ) were added to glioma cells, no difference was observed compared to the addition of Paclitaxel alone (data not shown). This indicates that they do not have synergistic activities, but experiments with different LNC-Paclitaxel dilution and/or peptide concentrations will be proceeding. We showed that a single injection of the NFL-TBS.40-63 peptide at 5 mм in an F98 rat glioma model decreased the tumour volume [15], while at $1 \mathrm{~mm}$ no significant difference was observed with non-treated rats. As the final concentration of NFL-TBS.40-63 peptide is $0.27 \mathrm{~mm}$ in the in vivo experiments (Fig. 4), it clearly shows that only Paclitaxel is responsible for the decrease of the tumour volume.

The LNC are localized mostly around the tumour (Fig. 4B), and this observation can be linked with results of toxicity. CED allows to overcome the limited distribution volume of LNC by allowing them to diffuse in the tumour and also in the healthy tissue surrounding the tumour, which is composed mainly of glial and vascular cells. In the tumour, where cells are very proliferative, the LNC can be rapidly captured and degraded, and thus the release of Paclitaxel can inhibit cells growth. Consequently, the presence of $\mathrm{DiD}$ in the tumour will rapidly decrease. On the opposite, the LNC around the tumour is captured by astrocytes or vascular cells. Because the Paclitaxel entrapped in LNC has a limited effect on these cells, they are not eliminated and thus DiD can stay longer in them (Fig. 3) [10]. Alternatively, the LNC is first incorporated into glioblastoma, which then can transdifferentiate into vascular endothelial cells [20], and thus surround the tumour.
Morphometrical studies show that LNC without Paclitaxel did not affect the tumour size (Fig. 4D), whether they are functionalized or not with NFL-TBS.40-63 peptide. These results are concordant with previous studies showing no effect of blank LNC in rat bearing respectively F98 and 9L glioma model [10,21]. Here, we demonstrate that a single injection of LNC-Paclitaxel-NFL reduces the glioma growth more efficiently than LNC-Paclitaxel (75\% versus $60 \%$. This indicates that the delivery and the efficiency of these nanovectors can be improved using the NFL-TBS.40-63 peptide, and thus represent a promising tool in glioma treatment using Paclitaxel or other lipophilic drugs.

\section{Conclusions}

This work demonstrates that the NFL-TBS.40-63 peptide exhibits the ability to enhance delivery of lipid nanocapsules in mouse glioma cells and astrocytes. The delivery of Paclitaxel entrapped in LNC decreases glioma cells proliferation, but has no effect on healthy cells in vitro. In mouse bearing GL261 glioma, these LNC containing Paclitaxel and functionalized with NFLTBS.40-63 peptide present a stronger capacity to inhibit tumour growth compared to unfunctionalized LNC. Therefore, the NFLTBS.40-63 peptide provides an innovating tool to enhance drug delivery in nanovectors with its ability to penetrate in cells.

\section{Acknowledgements}

We are grateful to A. Pasquier for help with the evaluation of tumour volumes. This investigation was supported by the Association pour la Recherche sur le Cancer (ARC), Fonds Européens de Développement Régional (FEDER), Institut National du Cancer (INCA), and Ciblage Moléculaire et Applications Thérapeutiques (CIMATH) to J.E. J.B. was supported by la Région des Pays de la Loire and ARC.

\section{References}

[1] Stupp R, Roila F. Malignant glioma: ESMO clinical recommendations for diagnosis, treatment and follow-up. Ann Oncol 2009;20:126-8.

[2] Stupp R, Hegi ME, Mason WP, van den Bent MJ, Taphoorn MJ, Janzer RC, et al Effects of radiotherapy with concomitant and adjuvant temozolomide versus radiotherapy alone on survival in glioblastoma in a randomised phase II study: 5-year analysis of the EORTC-NCIC trial. Lancet Oncol 2009;10:459-66.

[3] Delion M, Moraru C, Almayrac F, Von Langsdorff D, Paquis P, Menei P. Glioblastoma incident studies from May 2006 to May 2007 in Angers and Nice. France. Neurochirurgie 2010:56:499-502.

[4] Delgado G, Potkul RK, Treat JA, Lewandowski GS, Barter JF, Forst D, et al. A phase $\mathrm{I} / \mathrm{II}$ study of intraperitoneally administered doxorubicin entrapped in cardiolipin liposomes in patients with ovarian cancer. Am J Obstet Gynecol 1989; 160:812-9.

[5] Lammers T, Hennink WE, Storm G. Tumour-targeted nanomedicines: principles and practice. Br J Cancer 2008;99:392-7.

[6] Menei P, Capelle L, Guyotat J, Fuentes S, Assaker R, Bataille B, et al. Local and sustained delivery of 5-fluorouracil from biodegradable microspheres for the radiosensitization of malignant glioma: a randomized phase II trial. Neurosurgery 2005;56:242-8.

[7] Salvati M, D'elia A, Frati A, Brogna C, Santoro A, Delfini R. Safety and feasibility of the adjunct of local chemotherapy with biodegradable carmustine (BCNU) wafers to the standard multimodal approach to high grade gliomas at first diagnosis. J Neurosurg Sci 2011:55:1-6.

[8] Muthu MS, Kulkarni SA, Xiong J, Feng SS. Vitamin E TPGS coated liposomes enhanced cellular uptake and cytotoxicity of docetaxel in brain cancer cells. Int J Pharm 2011;421:332-40.

[9] Heurtault B, Saulnier P, Pech B, Proust JE, Benoit JP. A novel phase inversionbased process for the preparation of lipid nanocarriers. Pharm Res 2002;19: 875-80

[10] Garcion E, Lamprecht A, Heurtault B, Paillard A, Aubert-Pouessel A, Denizot B, et al. A new generation of anticancer, drug-loaded, colloidal vectors reverses multidrug resistance in glioma and reduces tumor progression in rats. Mol Cancer Ther 2006:5:1710-22.

[11] Vanpouille-Box C, Lacoeuille F, Belloche C, Lepareur N, Lemaire L, LeJeune JJ, et al. Tumor eradication in rat glioma and bypass of immunosuppressive 
barriers using internal radiation with (188)re-lipid nanocapsules. Biomaterials 2011;28:6781-90.

[12] Huynh NT, Morille M, Bejaud J, Legras P, Vessieres A, Jaouen G, et al. Treatment of 9L gliosarcoma in rats by ferrociphenol-loaded lipid nanocapsules based on a passive targeting strategy via the EPR effect. Pharm Res 2011;28:3189-98.

[13] Said Hassane F, Saleh AF, Abes R, Gait MJ, Lebleu B. Cell penetrating peptides: overview and applications to the delivery of oligonucleotides. Cell Mol Life Sci 2010;67:715-26.

[14] Bocquet A, Berges R, Frank R, Robert P, Peterson AC, Eyer J. Neurofilaments bind tubulin and modulate its polymerization. J Neurosci 2009;29:11043-54.

[15] Berges R, Balzeau J, Peterson AC, Eyer J. A tubulin binding peptide targets glioma cells disrupting their microtubules, blocking migration and inducing apoptosis. Mol Ther 2012;20:1367-77.

[16] McCarthy KD, de Vellis J. Preparation of separate astroglial and oligodendroglial cell cultures from rat cerebral tissue. J Cell Biol 1980;85:890-902.

[17] Minkov I, Ivanova T, Panaiotov I, Proust J, Saulnier P. Reorganization of lipid nanocapsules at air-water interface. I. Kinetics of surface film formation. Colloids Surf B Biointerfaces 2005;45:14-23.
[18] Balzeau J, Peterson AC, Eyer J. The vimentin-tubulin binding site peptide (VimTBS.58-81) crosses the plasma membrane and enters the nuclei of human glioma cells. Int J Pharm 2012;423:77-83.

[19] Berges R, Balzeau J, Takahashi M, Prevost C, Eyer J. Structure-function analysis of the glioma targeting NFL-TBS.40-63 peptide corresponding to the tubulinbinding site on the light neurofilament subunit. PLOS One. http://dx.doi.org/ 10.1371/journal.pone.0049436. Available from: URL: <http://www.ncbi.nlm. nih.gov/pubmed/23152907>; 2012.

[20] Soda Y, Marumoto T, Friedmann-Morvinski D, Soda M, Liu F, Michiue H, et al. Transdifferentiation of glioblastoma cells into vascular endothelial cells. Proc Natl Acad Sci U S A 2011;108:4274-80.

[21] Allard E, Huynh NT, Vessieres A, Pigeon P, Jaouen G, Benoit JP, et al. Dose effect activity of ferrocifen-loaded lipid nanocapsules on a 9L-glioma model. Int J Pharm 2009;379:317-23.

[22] Vichon-Petit S, Jarnet D, Paillard A, Benoit JP, Garcion E, Menei P. In vivo evaluation of intracellular drug-nanocarriers infused into intracranial tumours by convection-enhanced delivery: distribution and radiosensitisation efficacy. J Neurooncol 2010;97:195-205. 